${ }^{1}$ Bradbury, E. M., Crane-Robinson, C., Phillips, D. M. P., Johns, E. W., and Murray, K., Nature, 205, 1315 (1965).

2 Boublik, M., Bradbury, E. M., and Crane-Robinson, C., Eur. J. Biochem., 14, 486 (1970).

${ }^{3}$ Bradbury, E. M., and Rattle, H. W. E., Eur. J. Biochem., 27, 270 (1972).

4 Giannioni, G., and Peacocke, A. R., Biochim. Biophys. Acta, 68, $157(1963)$

5 Johns, E. W., and Forrester, S., Biochem. J., 111, 371 (1969)

${ }^{6}$ Clark, R. J., and Felsenfeld, G., Nature New Biology, 229, 101 (1971).

${ }^{7}$ Mirsky, A. E., Burdick, C. J., Davidson, E. N., and Littan, V. C., Proc. US Nat. Acad. Sci., 61, 592 (1968)

8 Ord, M. G., and Stocken, L. A., Biochem. J., 107, 403 (1967).

9 Shepherd, G. R., Noland, B. J., and Hardin, J. M., Arch. Biochim. Biophys., 142, 229 (1971)

10 Zubay, G., and Doty, P., J. Mol. Biol., 1, 1 (1959).

11 Murray, K., Bradbury, E. M., Crane-Robinson, C., Stephens, R. M., Haydon, A. J., and Peacocke, A. R., Biochem. J., 120, 859 (1970).

12 Johns, E. W., Biochem. J., 104, 78 (1967).

13 Oth, A., and Desveux, V., J. Polymer Sci., 23, 713 (1957).

14 Allfrey, V. G., in Histones and Nucleohistones (edit. by Phillips, D. M. P.) (Plenum Press, London, 1971).

${ }^{15}$ Langan, T. A., Proc. US Nat. Acad. Sci., 64, 1267 (1969).

\section{Nuclear DNA Contents of Coelacanth Erythrocytes}

AMONG the living fishes, groups of widely different phylogenetic antiquity may be classified by equally diverse sets of characteristics, both morphometric and biochemical. One such character that has been used in the study of the relationships between the major groups is cellular DNA content. It is now well known that, among fishes, modern teleosts have the lowest diploid levels (as low as $0.8 \mathrm{pg}$ ) and that elasmobranchs have somewhat intermediate levels (3-15 pg). The Dipnoi have the highest levels among living vertebrates (160-285 pg), and these values are approached most closely by some (but by no means all) Amphibia, such as Necturus and Amphiuma (205 and 192 pg respectively) ${ }^{1,2}$.

Table 1 DNA-Feulgen Content of Erythrocyte Nuclei

\begin{tabular}{|c|c|c|c|}
\hline Species & $\begin{array}{l}\text { Number } \\
\text { of nuclei } \\
\text { measured }\end{array}$ & $\begin{array}{l}\text { Mean Feulgen dye } \\
\text { content in arbitrary } \\
\text { photometric units } \\
\pm \text { error of the mean }\end{array}$ & $\begin{array}{l}\text { DNA content } \\
\text { per diploid } \\
\text { genome } \\
\left(\mathrm{g} \times 10^{-12}\right)\end{array}$ \\
\hline $\begin{array}{l}\text { Xenopus laevis } \\
\text { Rana pipiens } \\
\text { Latimeria chalumnae }\end{array}$ & $\begin{array}{l}10 \\
10 \\
20\end{array}$ & $\begin{array}{r}47.5 \pm 2.2 \\
115.7 \pm 2.8 \\
99.7 \pm 1.7\end{array}$ & $\begin{array}{r}6.3 \\
15.3 \\
13.2\end{array}$ \\
\hline
\end{tabular}

Fresh blood was smeared on microscope slides and allowed to dry. Slides from all three species were fixed and stained as a single batch. The preparations were post-fixed in ethanol-acetic acid $(3: 1)$ for 3 min, hydrated, hydrolysed in $5 \mathrm{~N} \mathrm{HCl}$ for $1 \mathrm{~h}$ at $25^{\circ} \mathrm{C}$ and stained for $1 \mathrm{~h}$ with the Feulgen reagent. Dye contents of individual nuclei were measured by the two wavelength method of microspectrophotometry $\left(\lambda^{1}=560 \mathrm{~nm} ; \lambda^{2}=487 \mathrm{~nm}\right)$. The relative dye contents are given in arbitrary photometric units. The absolute DNA contents for Rana and Latimeria were estimated on an assumed value of $6.3 \mathrm{pg}$ per diploid genome for Xenopus ${ }^{5}$. The estimated value for Rana agreed with literature values ${ }^{6}$.

In view of this great diversity of nuclear DNA content in fishes, and indeed all vertebrates, it has not always been clear what level might be considered "primitive" and what "advanced"s. It would therefore be extremely interesting to know the nuclear DNA content of supposedly primitive organisms. We have studied blood samples of a live coelacanth Latimeria chalumnae Smith, captured by a recent American-BritishFrench expedition to the Comore Islands ${ }^{4}$. Cytophotometric measurements of Feulgen-stained erythrocyte nuclei show that the DNA content of Latimeria erythrocyte nuclei is $13.2 \mathrm{pg}$ (Table 1). (This confirms predictions about histological thin sections of coelacanth tissues ${ }^{2,7}$.) Coelacanths therefore have diploid DNA levels well above some Amphibia, such as Xenopus (6.3 pg per diploid cell $\left.{ }^{5}\right)$ and in the same range as Rana (15.3 $\mathrm{pg}$, Table 1) and elasmobranch fishes such as Squalus acanthias $^{2}(14.7 \mathrm{pg})$.

The DNA content in Latimeria was higher than would be expected in the ancestor of all tetrapods and we conclude that in the course of evolution from the original dipnoan-crossopterygian-amphibian stock, increase in the coelacanth genome has occurred. Thus increased cellular DNA contents have arisen many times, independently, in this whole assemblage.

The expedition was supported in part by the National Geographic Society and research by the US AEC.

\section{K. S. THOMSON J. G. GALL}

Department of Biology, Yale University,

New Haven, Connecticut

\section{W. CogGINS}

Biology Department,

Brookhaven National Laboratory, Upton, New York

Received October 4, 1972.

Callan, H. G. Proc, Roy, Soc. Lond, B, 181, 1062 (1972).

Pedersen, R. A., J. Exp. Zool., 177, 1 (1971).

3 Thomson, K. S., J. Exp. Zool., 180, 3 (1972).

4 Locket, N. A., and Griffith, R. W., Nature, 237, 175 (1972).

5 Dawid, I. B., J. Mol. Biol., 12, 3 (1965).

6 Bachmann, K., Histochemie, 22, (1970)

7 Vialli, M., Rend. First Lombardo Sci., Part 1, 91, 680 (1957).

\section{Trans- $\beta$-farnesene, Alarm Pheromone of the Green Peach Aphid, Myzus persicae (Sulzer)}

THE chemical structure of the repellent odour found in the cornicle secretion of the aphid $M$. persicae ${ }^{1}$ has been identified as trans- $\beta$-farnesene.

We used two different methods to obtain material for gas chromatographic and mass spectrum analysis. In the first, a stream of dry nitrogen was passed over a homogenate of $0.6 \mathrm{~g}$ of aphids into a cold trap $\left(-60^{\circ} \mathrm{C}\right)$. The collected material, dissolved in pentane, gave a positive bioassay by repelling other $M$. persicae on a radish plant. Gas chromatography (g.c.) at $115^{\circ} \mathrm{C}$ on an 'OV-17' column gave a single peak eluting at $7.5 \mathrm{~min}$. After elution of this peak a $3^{\circ} \mathrm{min}^{-1}$ programme to $190^{\circ} \mathrm{C}$ caused the elution of a large number of peaks beginning at $175^{\circ} \mathrm{C}$. A g.c. mass spectrum of the 7.5 min peak gave a molecular ion of $204 \mathrm{~m} \mathrm{e}^{-1}$ and three prominent ions in decreasing order of 69,93 , and $41 m e^{-1}$. Other characteristic ions were $120,133,161$, and $189 m e^{-1}$.

A second sample was prepared by soaking $2 \mathrm{ml}$. of $M$. persicae in $2 \mathrm{ml}$. of refrigerated pentane for 5 days, as separate observations showed that pentane caused cornicles to open and expel fluid. A single peak eluting at $6.5 \mathrm{~min}$ from a 4 foot, $15 \%$ stabilized 'DEGS' column at $100^{\circ} \mathrm{C}$ was passed over $M$. persicae feeding on radish. The aphids responded by withdrawal of stylets from the leaf and by walking from the leaf. An aliquot $(1 / 10)$ of the extract was purified by cold-trapping the 6.5 min peak from this column, and this also gave a positive bioassay. The hydrocarbon nature of the compound was verified by co-chromatography with $\mathrm{C}_{16}$ and $\mathrm{C}_{14}$ saturated hydrocarbons on a 6 foot 'UC-W98' $(10 \%)$ column at $150^{\circ} \mathrm{C}$. The active peak eluted shortly after $\mathrm{C}_{14}$ and by interpolation of elution times had a boiling point of $258^{\circ} \mathrm{C}$. A g.c.-mass spectrum of the active peak prepared in this manner also gave a molecular ion of $204 m e^{-1}$ with prominent ions of 69,93 , and $41 m e^{-1}$ and the characteristic ions $120,133,161$ and $189 m e^{-1}$. 